\title{
In vitro propagation and analysis of secondary metabolites in Glossogyne tenuifolia (Hsiang-Ju) - a medicinal plant native to Taiwan
}

\author{
Chia-Chen Chen ${ }^{1}$, Hung-Chi Chang ${ }^{2^{*}}$, Chao-Lin Kuo ${ }^{1}$, Dinesh Chandra Agrawal ${ }^{3}$, Chi-Rei Wu ${ }^{1}$ and Hsin-Sheng Tsay ${ }^{3 *}$
}

\begin{abstract}
Background: Glossogyne tenuifolia Cassini (Hsiang-Ju in Chinese) is a perennial herb native to Penghu Islands, Taiwan. The herb is a traditional anti-pyretic and hepatoprotective used in Chinese medicine. Several studies on G. tenuifolia have demonstrated its pharmacological values of antioxidation, anti-inflammation, immunomodulation, and cytotoxicity on several human cancer cell lines. Active compounds, oleanolic acid and luteolin in G. tenuifolia are affected by several factors, including climatic change, pathogens and agricultural practices. Plant population of G. tenuifolia has been severely affected and reduced considerably in natural habitat due to the use of herbicides by farmers. Also, collection of plant material from the natural habitat is restricted to a few months in a year. Therefore, the objective of the present study was to develop an efficient micropropagation protocol for $\mathrm{G}$. tenuifolia. The study also aimed to investigate the influence of in vitro growth environment on the active compounds in in vitro shoots, tissue culture raised greenhouse plants; compare the values with wild plants and commercially available crude drug.

Results: Half-strength MS (Murashige and Skoog) basal medium supplemented with 0.1 mg/L 6-benzyladenine (BA) and $0.1 \mathrm{mg} / \mathrm{L}$ a-naphthaleneacetic acid (NAA) induced the maximum average number of shoots (7.3) per shoot tip explant excised from in vitro grown seedlings. Induction of rooting in cent percent in vitro shoots with an average number of 6.6 roots/shoot was achieved on $1 / 2$ strength MS medium supplemented with $3.0 \mathrm{mg} / \mathrm{L}$ indole-3-acetic acid (IAA). The rooted plantlets acclimatized successfully in the greenhouse with a 100\% survival rate. HPLC analysis revealed that the quantity of oleanolic acid and luteolin in in vitro shoots, tissue culture plants in the greenhouse, wild type plants and commercial crude drug varied depending upon the source. The oleanolic acid and luteolin contents were found to be significantly higher $(16.89 \mathrm{mg} / \mathrm{g}$ and $0.84 \mathrm{mg} / \mathrm{g}$, respectively) in 3-month old tissue culture raised plants in greenhouse compared to commercially available crude drug $(6.51 \mathrm{mg} / \mathrm{g}, 0.13 \mathrm{mg} / \mathrm{g}$, respectively).

Conclusions: We have successfully developed an in vitro propagation protocol for $\mathrm{G}$. tenuifolia which can expedite its plant production throughout the year. The contents of oleanolic acid and luteolin in the tissue culture raised plants in the greenhouse were significantly higher than the marketed crude drug demonstrating the practical application of the tissue culture technology. These findings may be very useful in micropropagation, germplasm conservation and commercial cultivation of G. tenuifolia. So far, there is no published report on tissue culture propagation of this important medicinal plant species.
\end{abstract}

Keywords: Glossogyne tenuifolia; In vitro plant regeneration; Medicinal plant; Micropropagation; Luteolin; Oleanolic acid; Shoot tip culture

\footnotetext{
*Correspondence: changhungchi@cyut.edu.tw; hstsay@cyut.edu.tw

²Department of Golden-Ager Industry Management, Chaoyang University of

Technology, Taichung, Taiwan

${ }^{3}$ Department of Applied Chemistry, Chaoyang University of Technology,

No.168, Gifong E. Rd., Wufong 41349 Taichung, Taiwan

Full list of author information is available at the end of the article
} 


\section{Background}

Medicinal herbs have played a significant role in maintaining human health and improving the quality of life for thousands of years. Many active phytochemicals, including flavonoids, terpenoids, lignans, sulfides, polyphenolics, carotenoids, coumarins, saponins, plant sterols, curcumins, and phthalides, have been identified (Craig 1999). Some of these phytochemicals have been found to be potent antioxidants, metal chelators, or free radical scavengers, which may account for their health promoting properties (Cotell et al. 1996). Today, medicinal plants are important to the global economy as approximately $85 \%$ of traditional medicine preparations involve the use of plants or plant extracts (Vieira and Skorupa 1993). In the past few decades, there has been a resurging interest in the study and use of medicinal plants in health care and in recognition of the importance of medicinal plants to the health system (Hoareau and DaSilva 1999). This has led to an exponential rise in demand for herbal medicines, and also a considerable international awareness about the dwindling supply of the world's medicinal plants. Therefore, all possible modes of plant propagation and large scale cultivation have been explored. In our laboratory, tissue culture techniques have been used successfully for propagation of several medicinally important plant species (Tsay 1999; Nalawade et al. 2003; Mulabagal and Tsay 2004; Tsay and Agrawal 2005; Chen et al. 2006 and Chang et al. 2007). Plants propagated by tissue culture have been reported to show less variation in the content of secondary metabolites than their cultivated or wild counterparts (Yamada et al. 1991).

G. tenuifolia Cassini belonging to the family Asteraceae originates from Penghu Islands, Taiwan (Li 1978). The perennial herb has been used to make traditional healthy food and herbal tea on the island for a long time. It is a traditional anti-pyretic and hepatoprotective used in the Chinese system of medicine (Anonymous 1999). Plant decoction has been used for treatment of lung diseases, chronic nephritis, edema and prevention of sunstroke (Xu 1972). The main active compounds of G. tenuifolia are luteolin, luteolin-7-glucoside and oleanolic acid (Anonymous 1999). Several studies on G. tenuifolia have demonstrated its pharmacological values of antioxidation (Wu et al. 2005a; Yang et al. 2006), anti-inflammation (Wu et al. 2004; Hsu et al. 2005); immunomodulation (Ha et al. 2006) and cytotoxicity on several human cancer cell lines (Hsu et al. 2005). The ethanol extracts of G. tenuifolia showed strong ROS scavenging (antioxidant) activity in both cell free and cell based systems (Wu et al. 2005b). Also, glossogin, an effective component of G. tenuifolia has been found to be a promising chemotherapeutic agent against lung cancer (Hsu et al. 2008). It was demonstrated that the bioactive fraction 'Fr. C' of G. tenuifolia significantly inhibited the proliferation of A549 lung cancer cells
(Hsu et al. 2011). G. tenuifolia extract reportedly reduces the synthesis of the inflammatory mediator in activated murine macrophages RAW264.7 via an NF- $\mathrm{kB}$-dependent pathway (Wu et al. 2004). G. tenuifolia extract has also been found to inhibit the synthesis of a pro-inflammatory mediator in activated murine peritoneal macrophages, partially via NF-jB-dependent pathways (Ha et al. 2006). In another study, G. tenuifolia extract suppressed the survival of mature osteoclasts by inhibiting osteoclast survival signaling pathways including NF-B, JNK, p38 and Akt, indicating its potential in the osteoclast-related diseases such as osteoporosis (Wang et al. 2014).

Flavor of 'Xiang-Ru tea' (made from G. tenuifolia) is very popular in Taiwan. The Kaohsiung District Agricultural Improvement Station has developed canned 'Xiang$\mathrm{Ru}$ tea' and 'Xiang-Ru jelly', and Penghu County farmers have come out with 'Xiang-Ru tea' bags. Additionally, other G. tenuifolia products and technologies are being developed, indicating an immense economic potential of the herb. However, the supply of natural plant material is seasonal and restricted to only a few months. Due to these constraints, production of G. tenuifolia plants having higher levels of active compounds and sustainability of its supply throughout the year are important issues. The development of a micropropagation protocol of G. tenuifolia offers the potential to alleviate these problems.

The purpose of this study was to develop a protocol for in vitro propagation of G. tenuifolia. The study also aimed to estimate the quantities of luteolin and oleanolic acid compounds in tissue culture raised plants; compare them with the quantities found in wild types and commercial crude drug using High-performance liquid chromatography (HPLC). The method developed in the present study can be applied for the mass production of true-to-type $G$. tenuifolia plants of superior genotypes at a commercial scale.

\section{Methods}

\section{Establishment of aseptic cultures}

Seeds of G. tenuifolia were collected from Penghu Islands, Taiwan. Wild type plant materials were collected from Chimei and Wangan islands, Taiwan. Samples of commercial drug of G. tenuifolia were obtained from the authorized source. Seeds were surface disinfected by washing several times with sterile distilled water, followed by dipping in $70 \%(\mathrm{v} / \mathrm{v})$ ethanol for $10 \mathrm{~s}$, then immersing in a solution of $1 \%(\mathrm{v} / \mathrm{v})$ sodium hypochlorite containing 1 drop of Tween-20 for $5 \mathrm{~min}$. Final washing consisted of 3 rinses of $5 \mathrm{~min}$ each in sterile distilled water. Thereafter, to raise in vitro seedlings, the disinfected seeds were cultured on $1 / 2 \mathrm{X}$ (half), and $1 \mathrm{X}$ (full) strength of macro, micro nutrients and vitamins of Murshige and Skoog's (Murashige and Skoog 1962) medium, hereinafter referred as MS basal medium. The $\mathrm{pH}$ of the culture media was 
adjusted to $5.7 \pm 0.1$ before autoclaving. All media were gelled with $0.9 \%$ Difco Bacto-agar (Difco Laboratories, Detroit, MI, USA).

\section{Multiple shoots induction}

For induction of multiple shoots in G. tenuifolia, initial experiments were performed to find out a suitable culture medium, hence four different basal media, i.e. MS (Murashige and Skoog 1962); WPM - Woody plant medium (Lloyd and McCown 1981); B5 (Gamborg et al. 1968); and N6 (Chu et al. 1975); different concentrations of plant growth regulators (PGRs) e.g. BA (6-benzyladenine), Kin (Kinetin) and NAA ( $\alpha$-naphthaleneacetic acid); and different concentrations of sucrose were tested in a randomized design. These trials gave us some idea of the growth regulators and the best basal medium needed to induce shoot induction in G. tenuifolia. Thereafter, shoot tips ( 0.8 to $1 \mathrm{~cm}$ long) were excised from 5 weeks old in vitro raised seedlings and were cultured on MS basal medium supplemented with $0.1,0.5,1.0 \mathrm{mg} / \mathrm{L}$ of 6-benzyladenine (BA) or $0.1,0.5,1.0 \mathrm{mg} / \mathrm{L}$ of kinetin and a fixed concentration $(0.1 \mathrm{mg} / \mathrm{L})$ of $\alpha$-naphthaleneacetic acid (NAA), 3\% sucrose and $0.9 \%$ agar. The $\mathrm{pH}$ of all media was adjusted to $5.7 \pm 0.1$. Glass bottle $(650 \mathrm{ml}$ capacity), each having $100 \mathrm{ml}$ of medium was used as culture vessel. After inoculation, the cultures were incubated in a growth room at $25 \pm{ }^{\circ} \mathrm{C}$, with a light and dark period of $16 / 8 \mathrm{hr}$ and a light intensity of $34 \mu \mathrm{mol} / \mathrm{m}^{2} \mathrm{~s}$. For fresh weight determination, the shoot cultures were gently pressed on sterile filter papers to remove excess water and weighed. The developing shoot clusters were sub-cultured onto the same medium composition every four weeks for further shoot proliferation and elongation of shoots.

\section{Container closure}

This experiment was carried out to test the influence of the type of container closure optimum for in vitro shoot cultures of G. tenuifolia. Glass bottles used as culture vessels were closed (sealed) with 4 dispensable papers (DP4) or with 2 layers of aluminum foil (AF2). In case of DP4, culture containers were additionally closed with a layer of parafilm which was removed after 2 weeks to facilitate a better gas exchange.

\section{Rooting of in vitro shoots}

For induction of rooting, in vitro shoots were cultured in $1 / 2 \mathrm{X}$ MS basal medium supplemented with Indole-3acetic acid (IAA) at $0.5,1,3$ and $5 \mathrm{mg} / \mathrm{L}$ concentrations or Idole-3-butyric acid (IBA) at 0.05, 0.1, 0.5 and $1 \mathrm{mg} / \mathrm{L}$ concentrations. Sucrose (3\%) and agar $(0.9 \%)$ was added to all the media. Observations were recorded after 35 days of culture.

\section{Hardening and survival of tissue culture plants}

Rooted plantlets were removed from the culture vessels, rinsed with water to remove the medium, and then transferred to plastic pots (9 $\mathrm{cm}$ diameter) containing a mixture of peat soil: perlite: vermiculite $(1: 1: 1 \mathrm{v} / \mathrm{v})$ in the greenhouse. The plants were watered once a day. Initially, a higher humidity was maintained by keeping the pots in a tray having water. Each pot was covered with a thin transparent polyethylene bag (sachet). After one week, one top corner of the sachet was cut. During the third week, a similar cut was made on the other side of the sachet. This sachet was completely removed in the fourth week. During the fifth week, pots were taken out of the tray. The data on survival of plants was recorded after five weeks of transfer to the greenhouse.

\section{HPLC analysis of tissue culture plants and commercial crude drug}

Reagents, materials and conditions

HPLC-grade methanol was purchased from Merck (Germany). Pump (L-2130), auto injector (L-2200) and diode array detector system (L-2450) used were from Hitachi. Symmetry Water Column $C_{18}(5 \mu \mathrm{m}, 4.6 \times$ $250 \mathrm{~mm}$ ) and Milli Q water (Millipore, Milford, MA, USA) were used for all the analysis carried out at room temperature. The mobile phase for luteolin was a gradient eluting with acetonitrile/water $(0.5 \%$ acetic acid) (from 20:80 to 100:0, by v/v) at $1 \mathrm{ml} / \mathrm{min}$ over $47 \mathrm{~min}$. The eluent was monitored at $245 \mathrm{~nm}$. While, mobile phase for oleanolic acid was a mixture of reagent acetonitrile and water (05\% acetic acid) (90:10) at $1 \mathrm{ml} / \mathrm{min}$ over $15 \mathrm{~min}$. The eluent was monitored at $210 \mathrm{~nm}$.

\section{Preparation of HPLC standard and samples}

Luteolin (ChromaDex) and oleanolic acid (Fluka Analytical) standard samples were purchased from Sigma-Aldrich Co. LLC. Standard solutions were prepared by dissolving $5 \mathrm{mg}$ of each in $5 \mathrm{ml}$ of Ethanol. Dissolved solutions $\left(1.0 \mathrm{mg} \mathrm{ml}^{-1}\right)$ were filtered through a $0.22 \mu \mathrm{m}$ filter (Millipore, USA) and further diluted to the concentration of

(1) For Luteolin: 1.0, 2.0, 4.0, 8.0 and $16 \mathrm{mg} \mathrm{l}^{-1}$.

(2) For Oleanolic acid: 5.0, 10.0, 20.0, 40.0, 80.0 and $160.0 \mathrm{mg} \mathrm{l}^{-1}$.

Calibration curves for standards were established and high linearity (r2 $>0.999)$ was obtained for each calibration curve. Standard solution $(10 \mu \mathrm{l})$ was used for HPLC injections. Calibration graphs were plotted based on linear regression analyses of the peak areas in response to concentrations of standards injected. The repeatability of the migration time and peak areas of Luteolin and 
oleanolic acid in the experiment were determined under the optimum conditions. Samples of in vitro shoots for the HPLC analysis were collected from the culture vessels and their fresh weights were recorded. The samples were then freeze-dried for $24 \mathrm{~h}$ and their dry weights were determined. Fraction (100 mg) of each dried sample was crushed into fine powder and dissolved in $10 \mathrm{ml}$ of ethanol. It was ultra-sonicated for $10 \mathrm{~min}$ and the supernatant was collected after centrifugation (5000 rpm, $10 \mathrm{~min})$. This process was repeated three times for each sample. After filtration, the combined ethanol extracts were evaporated to dryness with the help of a rotary evaporator. The residue was dissolved in $10 \mathrm{ml}$ ethanol and filtered through a $0.22 \mu \mathrm{m}$ (Millipore, USA) membrane before analysis.

\section{Statistical analysis}

Each treatment consisted of thirty replicates and each experiment was repeated three times. Data were statistically analyzed for least significant difference (LSD) using SAS 8.2 statistical software (SAS Institute Inc 2001).

\section{Results and discussion}

\section{Induction of multiple shoots}

Surface-sterilized seeds of G. tenuifolia inoculated on different basal media commenced gemination after 3 days of inoculation and a maximum $50 \%$ of seed germination at day 15 was recorded. The induction of multiple shoots in explants varied with cytokinin type and concentration (Table 1) (Figure 1). The response in medium supplemented with BA $(1.0 \mathrm{mg} / \mathrm{L})+\mathrm{NAA}$ $(0.1 \mathrm{mg} / \mathrm{L})$ was higher compared to the medium with kinetin + NAA, or devoid of growth regulators. The maximum average number of shoots $(7.4 \pm 0.6)$ in $100 \%$ explants was obtained on $1 / 2 \mathrm{X}$ MS medium supplemented with BA $(1.0 \mathrm{mg} / \mathrm{L})+$ NAA $(0.1 \mathrm{mg} / \mathrm{L})$ and $3 \%$ sucrose after 35 days of inoculation. Also, this treatment resulted in the maximum fresh weight $(894.9 \pm 78.4)$ per explant.
Multiple shoots developed directly from the lateral bud meristems. Kinetin and medium without plant growth regulators though supported elongation of shoots, but responses were lower compared to BA which induced a higher number of multiple shoots at all three concentrations $(0.1,0.5$ and $1.0 \mathrm{mg} / \mathrm{L})$ (Table 1$)$.

Similar to the results in the present study, the differential effect of various concentrations of BAP on the induction of multiple shoots has earlier been reported for Gossypium (Agrawal et al. 1997), Salix (Agrawal and Gebhardt 1994), Pisum (Jackson and Hobbs 1990) Phaseolus (McClean and Grafton 1989) and Glycine (Cheng et al. 1980). Akin to the present study, BAP was the most effective cytokinin in all these reports, indicating a particular cytokinin preference for multiple shoot induction in certain tissues.

\section{Container closure}

Our experiment to find out the type of container closure optimum for in vitro shoot cultures of $G$. tenuifolia showed that the maximum average number of multiple shoots (9.7/explant) and average fresh weight of each shoot $(472.1 \mathrm{mg})$ was obtained when each culture container was closed with 2 layers of aluminum foil (AF). The container closure with 4 dispensable papers (DP4) resulted in a lower average number of shoots to 7.1/explant and fresh weight of $326.2 \mathrm{mg}$ (Table 2) (Figure 2).

To maintain the sterility of cultures, it is essential to close culture containers with some closure. Different types of container closures are commonly used. Some closures cause restriction of gaseous exchange between the container atmosphere and the outside environment (Buddendorf-Joosten and Woltering 1994), which can result in poor aeration and hyperhydric condition of cultures. It has been reported that the type of closure affects gaseous exchange, availability of water, micronutrients, and balance of hormones in the culture container

Table 1 Influence of BA and Kin on induction of multiple shoots in seedling-derived shoot tip explants of G. tenuifolia

\begin{tabular}{cccccccc}
\hline $\begin{array}{c}\text { Cytokinin* } \\
(\mathbf{m g} / \mathbf{L})\end{array}$ & $\begin{array}{c}\text { NAA } \\
(\mathbf{m g} / \mathbf{L})\end{array}$ & $\begin{array}{c}\text { No. of explants } \\
\text { cultured }\end{array}$ & $\begin{array}{c}\text { Shoot length } \\
(\mathbf{m m})^{* *}\end{array}$ & $\begin{array}{c}\text { Explants induced } \\
\text { multiple shoots (\%)** }\end{array}$ & $\begin{array}{c}\text { Average no. of } \\
\text { shoots/explant }\end{array}$ & $\begin{array}{c}\text { Explants induced } \\
\text { callus (\%)** }\end{array}$ & $\begin{array}{c}\text { Fresh weight/ } \\
\text { shoot (mg) }\end{array}$ \\
\hline 0 & 0 & 30 & $26.7 \pm 2.1 \mathrm{~cd}$ & $53.3 \pm 9.1 \mathrm{bc}$ & $1.8 \pm 0.3 \mathrm{c}$ & $0.0 \pm 0.0 \mathrm{~d}$ & $128.0 \pm 16.7 \mathrm{~d}$ \\
0 & 0.1 & 30 & $40.8 \pm 2.2 \mathrm{a}$ & $50.0 \pm 9.1 \mathrm{bc}$ & $1.8 \pm 0.2 \mathrm{c}$ & $56.7 \pm 9.0 \mathrm{~b}$ & $379.5 \pm 33.4 \mathrm{C}$ \\
BA 0.1 & 0.1 & 30 & $24.4 \pm 1.3 \mathrm{~d}$ & $93.3 \pm 4.6 \mathrm{a}$ & $4.1 \pm 0.4 \mathrm{~b}$ & $33.3 \pm 8.6 \mathrm{C}$ & $364.1 \pm 43.6 \mathrm{C}$ \\
BA 0.5 & 0.1 & 30 & $24.2 \pm 1.4 \mathrm{~d}$ & $100.0 \pm 0.0 \mathrm{a}$ & $7.3 \pm 0.6 \mathrm{a}$ & $13.3 \pm 6.2 \mathrm{~d}$ & $666.2 \pm 68.4 \mathrm{~b}$ \\
BA 1.0 & 0.1 & 30 & $26.2 \pm 1.7 \mathrm{~cd}$ & $100.0 \pm 0.0 \mathrm{a}$ & $7.4 \pm 0.6 \mathrm{a}$ & $95.0 \pm 4.9 \mathrm{a}$ & $894.9 \pm 78.4 \mathrm{a}$ \\
Kin 0.1 & 0.1 & 30 & $40.1 \pm 3.5 \mathrm{a}$ & $43.3 \pm 9.0 \mathrm{C}$ & $1.8 \pm 0.2 \mathrm{C}$ & $50.0 \pm 9.1 \mathrm{bc}$ & $319.8 \pm 44.2 \mathrm{C}$ \\
Kin 0.5 & 0.1 & 30 & $32.8 \pm 2.4 \mathrm{bc}$ & $70.0 \pm 8.4 \mathrm{~b}$ & $2.5 \pm 0.3 \mathrm{C}$ & $80.0 \pm 7.3 \mathrm{a}$ & $306.7 \pm 32.6 \mathrm{C}$ \\
Kin 1.0 & 0.1 & 30 & $34.6 \pm 2.1 \mathrm{ab}$ & $56.7 \pm 9.0 \mathrm{bc}$ & $2.3 \pm 0.3 \mathrm{C}$ & $100.0 \pm 0.0 \mathrm{a}$ & $253.0 \pm 26.0 \mathrm{~cd}$ \\
\hline
\end{tabular}

*Basal medium: 1/2X MS basal medium supplemented with 3\% sucrose and 0.9\% Difco Bacto-agar. Observations were recorded after 35 days of culture.

**Means followed by the same letter are not significantly different at $5 \%$ level by LSD (least significant difference) test. 


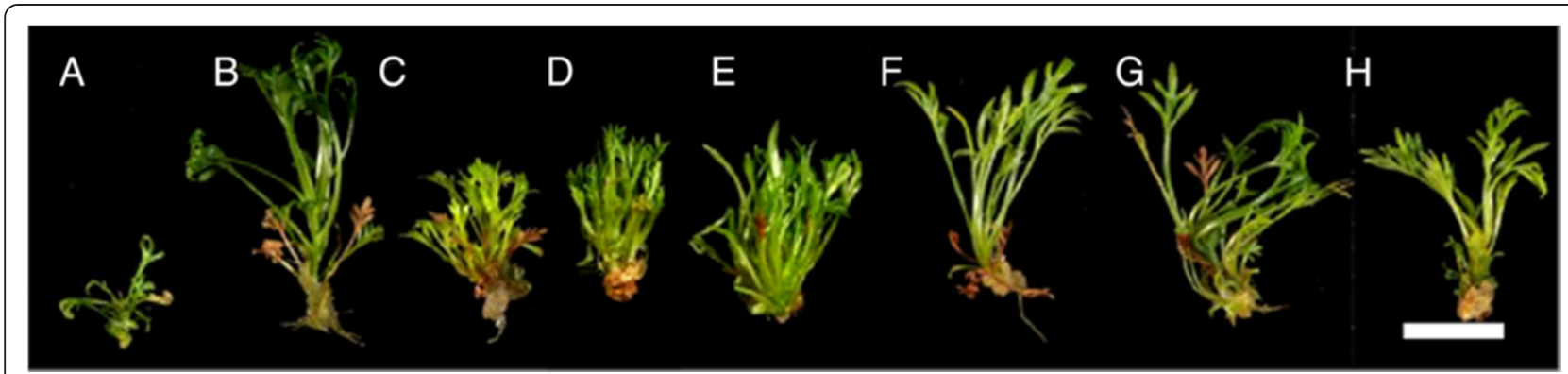

Figure 1 Influence of BA and Kinetin on induction of multiple shoots in seedling-derived shoot tip of G. tenuifolia. (A) $1 / 2 X$ MS basal medium without PGRs; (B) $0.1 \mathrm{mg} / \mathrm{L} \mathrm{NAA}$ (C) $0.1 \mathrm{mg} / \mathrm{L} \mathrm{BA}$ and $0.1 \mathrm{mg} / \mathrm{L} \mathrm{NAA}$ (D) $0.5 \mathrm{mg} / \mathrm{L}$ BA and $0.1 \mathrm{mg} / \mathrm{L} \mathrm{NAA}$ (E) $1 \mathrm{mg} / \mathrm{L}$ BA and $0.1 \mathrm{mg} / \mathrm{L}$ NAA; (F) $0.1 \mathrm{mg} / \mathrm{L}$ Kin and $0.1 \mathrm{mg} / \mathrm{L} \mathrm{NAA;} \mathrm{(G)} 0.5 \mathrm{mg} / \mathrm{L}$ Kin and $0.1 \mathrm{mg} / \mathrm{L} \mathrm{NAA;}(\mathbf{H}) 1 \mathrm{mg} / \mathrm{L}$ Kin and $0.1 \mathrm{mg} / \mathrm{L} \mathrm{NAA}$. (Bar $=1 \mathrm{~cm})$.

(Kataeva et al. 1991; Lai et al. 2005; Chen et al. 2006; Tsay et al. 2006). Also, growth rate and other physiological and morphological characteristics of plants developed under in vitro conditions can be influenced by the physical and chemical micro-environments of culture containers (Walker et al. 1988). Different species show different requirement with respect to container closures. Hence, it is important to optimize a closure type in a micropropagation protocol of a particular plant species.

\section{Rooting of in vitro shoots}

Between the two auxins tested, the response of IAA was found better compared to IBA for induction of rooting in in vitro shoots of G. tenuifolia. Half strength $(1 / 2 \mathrm{X}) \mathrm{MS}$ basal medium supplemented with $3.0 \mathrm{mg} / \mathrm{L}$ IAA induced an average number of 6.6 roots/shoot in $100 \%$ shoots (Table 3). The response of IBA in the medium was also comparable (6.3 roots/shoot), however, with IAA, the percentage of rooting was lower (83.3). Higher concentrations of both the auxins $(>3.0 \mathrm{mg} / \mathrm{L}$ IAA and $>0.1 \mathrm{mg} / \mathrm{L}$ IBA) induced more average number of roots per shoot, however, shoots induced callus at the base which affected the survival rates of the rooted shoots in the greenhouse (Table 3). The promotory effect of a lower salt concentration of MS on in vitro rooting of shoots has been reported for Gossypium (Agrawal et al. 1997), Philodendron spp. (Maene and Debergh 1985). Different plant species respond differently to auxins for the induction of rooting. Some plant species, even do not require any auxin supplemental in the medium for rooting (Agrawal and Gebhardt 1994), hence it is desirable to optimize the type and concentration of an auxin in a micropropagation protocol of a particular plant species.

\section{Hardening and survival of tissue culture plants}

Hardening and $100 \%$ survival of tissue culture plants was achieved on the peat soil: perlite: vermiculite $(1: 1: 1 \mathrm{v} / \mathrm{v})$ mix in plastic pots kept in the greenhouse. Covering of plants with transparent sachets raised humidity levels, crucial for the survival of tissue culture plants of G. tenuifolia. Normal flowering and seed formation (Figure 3A, B) was observed in all the tissue culture raised plants after $3^{1 / 2}$ months of transfer to pots.

\section{HPLC analysis of secondary metabolites}

HPLC analysis revealed the varying quantities of oleanolic acid and luteolin in in vitro shoots, tissue culture plants in the greenhouse, wild type and commercial

Table 2 Influence of container closure type on induction of multiple shoots in G. tenuifolia

\begin{tabular}{ccccc}
\hline Ventilation closure* & Culture medium & $\begin{array}{c}\text { Explants induced multiple } \\
\text { shoots (\%)*** }\end{array}$ & $\begin{array}{c}\text { Average no. of } \\
\text { shoots/explant*** }\end{array}$ & $\begin{array}{c}\text { Fresh weight/shoot } \\
(\mathbf{m g})^{* * * *}\end{array}$ \\
\hline AF2 & $1 / 2$ X MS basal & $61.4 \pm 6.2 \mathrm{~b}$ & $2.3 \pm 0.2 \mathrm{C}$ & $128.7 \pm 6.8 \mathrm{C}$ \\
AF2 & NAA (0.1) + BA (0.1) & $100.0 \pm 0.0 \mathrm{a}$ & $9.7 \pm 0.4 \mathrm{a}$ & $472.1 \pm 15.2 \mathrm{a}$ \\
DP4** & $1 / 2$ X MS basal & $68.6 \pm 2.5 \mathrm{~b}$ & $2.5 \pm 0.1 \mathrm{C}$ & $73.5 \pm 2.8 \mathrm{~d}$ \\
DP4 & NAA (0.1) + BA (0.1) & $100.0 \pm 0.0 \mathrm{a}$ & $7.1 \pm 0.5 \mathrm{~b}$ & $326.2 \pm 12.2 \mathrm{~b}$ \\
\hline
\end{tabular}

*Basal medium: $1 \frac{1}{2}$ X MS basal salts supplemented with 3\% sucrose and 0.9\% Difco Bacto-agar. Concentrations of PGRs in the parentheses represent mg/L values. Observations were recorded after 35 days of culture.

**AF2 = Culture container closed with 2 layers of Aluminum foil;

DP4 = Culture container sealed with 4 dispense papers. Culture containers were initially sealed with 4 dispense paper and parafilm layers. After 2 weeks, parafilm layer was removed to facilitate ventilation.

${ }^{* * *}$ Means followed by the same letter are not significantly different at $5 \%$ level by LSD (least significant difference) test. 


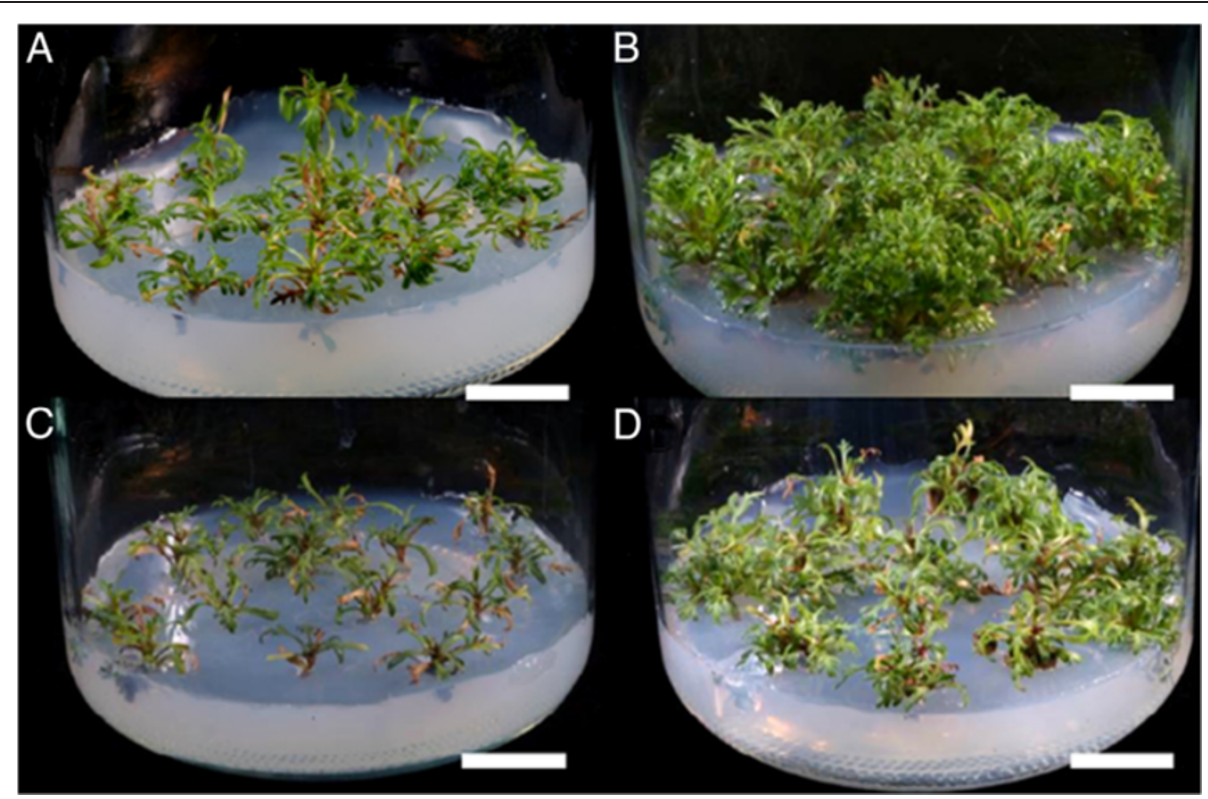

Figure 2 Influence of container closure type on induction of multiple shoots in G. tenuifolia. (A) Sealed with 2 layers of AF; 1/2X MS basal (B) Sealed with 2 layers of AF; BA $0.1 \mathrm{mg} / \mathrm{L}+0.1 \mathrm{mg} / \mathrm{L}$ (C) Sealed with 4 layers of DPs; $122 \mathrm{X}$ MS basal; (D) Sealed with 4 layers of DPs; BA $0.5 \mathrm{mg} / \mathrm{L}+$ NAA $0.1 \mathrm{mg} / \mathrm{L}$. (Bar $=2 \mathrm{~cm})$.

crude drug materials (Table 4). The oleanolic acid and luteolin contents were found to be significantly higher $\left(16.89 \mathrm{mg} / \mathrm{g}\right.$ and $0.84 \mathrm{mg} / \mathrm{g}$, respectively) in $3 \frac{1}{2} 2$-month old tissue culture raised plants in greenhouse compared to commercially available crude drug $(6.51 \mathrm{mg} / \mathrm{g}$, $0.13 \mathrm{mg} / \mathrm{g}$, respectively). In comparison with the tissue culture plants in the greenhouse, the next best values of oleanolic acid and luteolin contents were recorded in wild type plants from Chimei and Wangan islands. There was only a marginal difference between the two wild type plant materials showing comparable quantities of both the active compounds. These compounds were present mostly in the aboveground parts of the plant. Only underground dried herbs of commercial crude drug showed oleanolic acid content, indicating probable mixing of aboveground parts with the underground parts or a wrong identification of the commercial crude drug. In vitro shoots growing under culture conditions on $1 / 2$ strength MS basal medium devoid of any growth regulators also showed the presence of active compounds $(3.29 \mathrm{mg} / \mathrm{g}$ of oleanolic acid and $0.47 \mathrm{mg} / \mathrm{g}$ of luteolin) indicating onset of biosynthetic pathways for production of these compounds at the culture stage itself. The lower quantities of the compounds in in vitro shoots in comparison to the tissue

Table 3 Influence of IAA and IBA concentrations on in vitro rooting of shoots of G. tenuifolia

\begin{tabular}{|c|c|c|c|c|c|}
\hline $\begin{array}{c}\text { Auxin } \\
(\mathrm{mg} / \mathrm{L})^{*}\end{array}$ & $\begin{array}{c}\text { Concentration } \\
(\mathrm{mg} / \mathrm{L})\end{array}$ & $\begin{array}{l}\text { No. of shoots } \\
\text { rooted }(\%)^{* *}\end{array}$ & $\begin{array}{l}\text { Average no. } \\
\text { of roots }\end{array}$ & $\begin{array}{c}\text { Callus } \\
\text { formation }\end{array}$ & $\begin{array}{c}\text { Plants survival in } \\
\text { greenhouse (\%) }\end{array}$ \\
\hline IAA & 0.5 & $53.3 \pm 9.1 b$ & $2.4 \pm 0.4 \mathrm{~cd}$ & - & 93.3 \\
\hline- & 1.0 & $63.3 \pm 8.8 b$ & $3.3 \pm 0.5 c$ & - & 100.0 \\
\hline \multirow[t]{2}{*}{-} & 3.0 & $100.0 \pm 0.0 \mathrm{a}$ & $6.6 \pm 0.7 b$ & + & 100.0 \\
\hline & 5.0 & $93.3 \pm 4.6 \mathrm{ab}$ & $9.5 \pm 0.9 \mathrm{a}$ & ++ & 96.7 \\
\hline \multirow[t]{4}{*}{$\mathrm{IBA}$} & 0.05 & $3.3 \pm 3.4 d$ & $0.1 \pm 0.1 \mathrm{e}$ & - & 90.0 \\
\hline & 0.1 & $16.7 \pm 6.8 c$ & $0.9 \pm 0.3 \mathrm{de}$ & - & 96.7 \\
\hline & 0.5 & $83.3 \pm 6.8 \mathrm{ab}$ & $6.3 \pm 0.7 b$ & + & 96.7 \\
\hline & 1.0 & $96.7 \pm 3.3 \mathrm{ab}$ & $8.6 \pm 0.7 a$ & +++ & 66.7 \\
\hline
\end{tabular}

*Basal medium: 1/2X MS basal medium supplemented with 3\% sucrose and 0.9\% Difco Bacto-agar. Observations were recorded after 35 days of culture. **Means followed by the same letter are not significantly different at $5 \%$ level by LSD (least significant difference) test.

-No callusing.

+Minimum callusing.

++ Moderate callusing.

+++ Maximum callusing. 

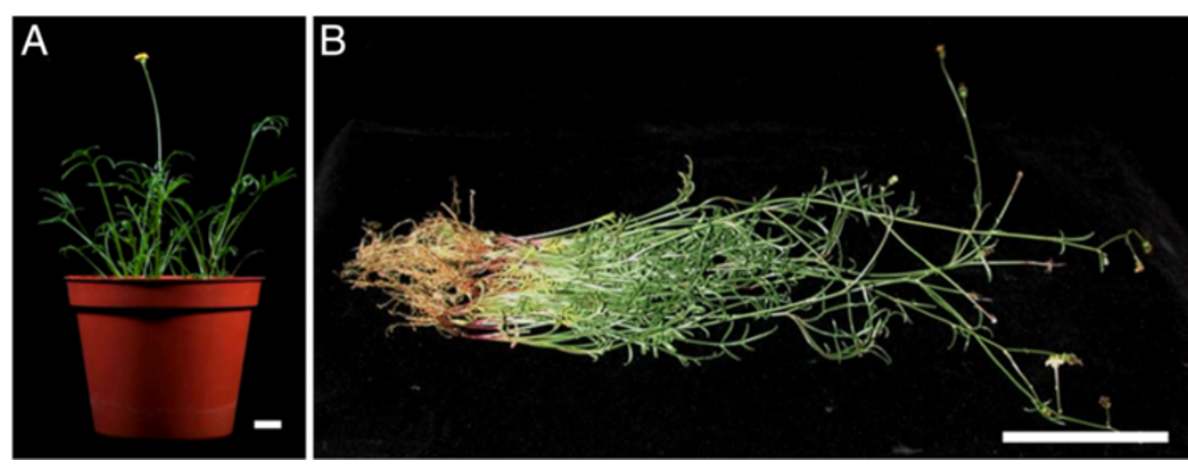

Figure 3 Tissue culture plants of G. tenuifolia. (A) Successfully acclimatized; (B) Tissue culture plants in greenhouse (31/2 month old). (Bar $A=1.3 \mathrm{~cm} ; \operatorname{Bar} B=6 \mathrm{~cm})$.

culture raised greenhouse plants may be due to differences in the maturity of the plant materials. Media supplemented with PGRs did not have significant influence on the contents of oleanolic acid and luteolin in in vitro shoots (Data not shown).

Similar to the present study, significantly higher amounts of emodin and physcion contents were observed in in vitro propagated shoots and tissue culturplants of Polygonum multiflorum compared to the marketed crude drug (Lin et al. 2003). Fairly high amounts of gentiopicroside and swertiamarin compounds were recorded in the aerial and underground parts of Gentiana davidii var. formosana compared to commercially available crude drug (Chueh et al. 2001). Yet in another study on Saussurea involucrata in our laboratory, the highest Syringetin and Rutin contents were recorded in petioles of two months old in vitro plants compared to the commercially available crude drug (unpublished results). The possible reasons for the enhanced levels of active compounds in tissue culture plants could be, that the plants collected for the crude drugs are grown under natural conditions and the contents of the active compounds may vary depending on the growth conditions, place and time of plant collections. Whereas, the tissue culture plants are grown under controlled growth and environmental conditions receiving an optimum supply of nutrients and other favorable growth conditions. Based on the results of the present study, it is evident that under defined culture conditions, it is possible to produce plants with higher contents of oleanolic acid and luteolin contents in a shorter time span and throughout the year.

\section{Conclusions}

In the present study, we have developed an in vitro propagation protocol for G. tenuifolia, an important medicinal plant native to Taiwan. HPLC analysis of tissue culture raised plants grown in the greenhouse have shown significantly higher levels of the active compounds compared to wild types and commercial crude drug, demonstrating the usefulness of the tissue culture technology. The results obtained in the present study have enormous significance, since so far there is no published report on micropropagation of this medicinally important plant species.

Table 4 HPLC analysis for luteolin and oleanolic acid contents in in vitro raised, wild and commercially available plant materials of Glossogyne tenuifolia

\begin{tabular}{|c|c|c|c|}
\hline Plant samples & Source/treatment & Oleanolic acid $(\mathrm{mg} / \mathrm{g} \text { of } \mathrm{dw})^{*}$ & Luteolin $(\mathrm{mg} / \mathrm{g} \text { of } \mathrm{dw})^{*}$ \\
\hline \multirow[t]{2}{*}{ Commercial crude drug } & Dried herbs (Aboveground) & 6.51 & 0.13 \\
\hline & Dried herbs (Underground) & 1.07 & none \\
\hline \multirow[t]{4}{*}{ Wild type } & Chimei Island (Aboveground) & 13.78 & 0.82 \\
\hline & Chimei Island (Underground) & none & none \\
\hline & Wangan Island (aboveground) & 14.58 & 0.72 \\
\hline & Wangan Island (Underground) & none & none \\
\hline In vitro shoots & $1 / 2 X$ MS basal medium (-PGRs) & 3.29 & 0.47 \\
\hline \multirow{2}{*}{$\begin{array}{l}\text { Tissue culture plants } \\
\text { (3 month old) in greenhouse }\end{array}$} & Aboveground parts & 16.89 & 0.84 \\
\hline & Underground parts & none & none \\
\hline
\end{tabular}

${ }^{*}$ dw: Freeze-dried weight. 


\section{Abbreviations}

GT: Glossogyne tenuifolia; MS: Murashige and Skoog (1962); B5: Gamborg et al. (1968); N6: Chu et al. (1975); WPM: Loyd and McCown (1981) woody plant medium; Kinetin: 6-furfurylamino purine; BA: N6-benzyladenine; NAA: a-naphthaleneacetic acid; IAA: Indole-3-acetic acid; IBA: Indole-3-butyric acid; HPLC: High performance liquid chromatography.

\section{Competing interests}

The authors declare that they have no competing interests.

\section{Authors' contributions}

CCC carried out the experimental work, CHC provided funding and designed the experiments, CLK identified the wild plant materials and provided other significant inputs during the study, DCA prepared the manuscript, CRW helped in analytical work, and HST provided laboratory facilities and important inputs in the manuscript preparation. All authors read and approved the final manuscript.

\section{Acknowledgements}

Research grant (NSC 100-2313-B-324-002) by the National Science Council, Taiwan is gratefully acknowledged.

\section{Author details}

${ }^{1}$ Department of Chinese Pharmaceutical Sciences and Chinese Medicine Resources, China Medical University, Taichung, Taiwan. ${ }^{2}$ Department of Golden-Ager Industry Management, Chaoyang University of Technology, Taichung, Taiwan. ${ }^{3}$ Department of Applied Chemistry, Chaoyang University of Technology, No.168, Gifong E. Rd., Wufong 41349 Taichung, Taiwan.

\section{Received: 18 February 2014 Accepted: 28 April 2014}

\section{Published: 24 June 2014}

\section{References}

Agrawal DC, Gebhardt K (1994) Rapid micropropagation of hybrid willow (Salix) established by ovary culture. J Plant Physiol 143(6):763-765

Agrawal DC, Banerjee AK, Kolala RR, Dhage AB, Nalawade SM, Kulkarni AV, Hazra S, Krishnamurthy KV (1997) In vitro induction of multiple shoots and plant regeneration in cotton (Gossypium hirsutum L.). Plant Cell Rep 16:647-652, doi:10.1007/BF01275508

Anonymous (1999) Zhong Hua Ben Cao (China Herbal). Shanghai Science and Technology Press, Shanghai, Vol. 7, p. 847

Buddendorf-Joosten JMC, Woltering EJ (1994) Components of the gaseous environment and their effects on plant growth and development in vitro. Plant Growth Regul 15:1-16

Cheng TY, Saka H, Voqui-Dinh TH (1980) Plant regeneration from soybean cotyledonary node segments in culture. Plant Sci Lett 19:91-99

Chang HC, Agrawal DC, Kuo CL, Wen JL, Chen CC, Tsay HS (2007) In vitro culture of Drynaria fortunei, a fern species source of Chinese medicine "Gu-Sui-Bu". In Vitro Cell Dev Biol-Plant 43:133-139, doi:10.1007/s11627-007-9037-6

Chen UC, Hsia CN, Agrawal DC, Tsay HS (2006) Influence of ventilation closures on plant growth parameters, acclimation and anatomy of leaf surface in Scrophularia yoshimurae Yamazaki - a medicinal plant native to Taiwan. Bot Stud 47:259-266

Chu CC, Wang CC, Sun CS, Hsu C, Yin KC (1975) Establishment of an efficient medium for anther culture of rice through comparative experiments on the nitrogen sources. Sci Sin 18:659-668

Chueh FS, Chen CC, Sagare AP, Tsay HS (2001) Quantitative determination of secoiridoid glucosides in in vitro propagated plants of Gentiana davidii var. formosana by high performance liquid chromatography. Planta Med 67:70-73

Cotell N, Bernier JL, Catteau JP, Pommery J, Wallet JC, Gaydou EM (1996) Antioxidant properties of hydroxy-flavones. Free Radic Biol Med 20:35-43

Craig WJ (1999) Health-promoting properties of common herbs. Am J Clin Nutr 70:491S-499S

Gamborg OL, Miller RA, Ojima K (1968) Nutrient requirements of suspension cultures of soybean root cells. Exp Cell Res 50:151-158, doi:10.1016/00144827(68)90403-5

Ha CL, Weng CY, Wang L, Lian TW, Wu MJ (2006) Immunomodulatory effect of Glossogyne tenuifolia in murine peritoneal macrophages and splenocytes. J Ethnopharmacol 107:116-125
Hoareau L, DaSilva E (1999) Medicinal plants: a re-emerging health aid. EJB Electronic J Biotech 2:56-70

Hsu HF, Houng JY, Chang CL, Wu CC, Chang FR, Wu YC (2005) Antioxidant activity, cytotoxicity, and DNA information of Glossogyne tenuifolia. J Agric Food Chem 53:6117-6125

Hsu HF, Houng JY, Kuo CF, Tsao N, Wu YC (2008) Glossogin, a novel phenylpropanoid from Glossogyne tenuifolia, induced apoptosis in A549 lung cancer cells. Food Chem Toxicol 46:3785-3791

Hsu HF, Wu YC, Chang CC, Houng JY (2011) Apoptotic effects of bioactive fraction isolated from Glossogyne tenuifolia on A549 human lung cancer cells. J Taiwan Inst Chem Eng 42:556-562

Jackson JA, Hobbs SLA (1990) Rapid multiple shoot production from cotyledonary node explants of Pea (Pisum sativum). In Vitro Cell Dev Biol 26:835-838

Kataeva NV, Alexandrova IG, Butenko RG, Dragavtceva EV (1991) Effect of applied and internal hormones on vitrification and apical necrosis of different plants cultured in vitro. Plant Cell Tiss Organ Cult 14:31-40

Lai CC, Lin HM, Nalawade SM, Fang W, Tsay HS (2005) Hyperhydricity in shoot cultures of Scrophularia yoshimurae can be effectively reduced by ventilation of culture vessels. J Plant Physiol 162(3):355-361

Li HL (1978) Glossogyne Cass. Flora of Taiwan. Epoch Publishing Co, Taipei, Taiwan, pp 870-871

Lin LC, Nalawade SM, Mulabagal V, Yeh MS, Tsay HS (2003) Micropropagation of Polygonum multiflorum THUNB and quantitative analysis of the anthraquinones emodin and physcion formed in in vitro propagated shoots and plants. Biol Pharm Bull 26(10):1467-1471

Lloyd G, McCown B (1981) Commercially feasible micropropagation of mountain laurel, Kalmia latifolia, by shoot tip culture. Intl Plant Prop Soc Proc 30:421-427

Maene L, Debergh P (1985) Liquid medium addition to established tissue cultures to improve elongation and rooting in vitro. Plant Cell Tissue Organ Cult 5:23-33

McClean P, Grafton KF (1989) Regeneration of dry bean (Phaseolus vulgaris L.) via organogenesis. Plant Sci 60:117-122

Mulabagal V, Tsay HS (2004) Plant cell cultures-An alternative and efficient source for the production of biologically important secondary metabolites. Int J Appl Sci Eng 2(1):29-48

Murashige T, Skoog F (1962) A revised medium for rapid growth and bioassays with tobacco tissue cultures. Physiol Plant 15:473-497, doi:10.1111/J.13993054.1962.TB08052.X

Nalawade SM, Sagare AP, Lee CY, Kuo CL, Tsay HS (2003) Studies on tissue culture of Chinese medicinal plant resources in Taiwan and their sustainable utilization. Bot Bull Acad Sinica 44:79-98

SAS Institute Inc (2001) SAS/STAT User's Guide. Version 8.2, vol 2. SAS Institute, USA, p 943

Tsay HS, Agrawal DC (2005) Tissue culture technology of Chinese medicinal plant resources in Taiwan and their sustainable utilization. Int J Appl Sci Eng $3: 215-223$

Tsay HS (1999) Tissue culture technology of medicinal herbs and its application in Taiwan. In: Chou CH, Waller GR, Reinhardt C (eds) Biodiversity and allelopathy: from organisms to ecosystems in the Pacific. Academia Sinica, Taipei, pp 137-144

Tsay HS, Lee CY, Agrawal DC, Basker S (2006) Influence of ventilation closure, gelling agent and explant type on shoot bud proliferation and hyperhydricity in Scrophularia yoshimurae - A medicinal plant. In Vitro Cell Dev Biol-Plant 42:445-449

Vieira RF, Skorupa LA (1993) Brazilian medicinal plants gene bank. Acta Hort 330:51-58

Walker PN, Heuser CW, Heinemann PH (1988) Micropropagation: studies of gaseous environments. Acta Hort 230:145-151

Wang SW, Kuoa HC, Hsu HF, Tu YK, Chenge T, Houng JY (2014) Inhibitory activity on RANKL-mediated osteoclastogenesis of Glossogyne tenuifolia extract. J Funct Food 6:215-223

Wu MJ, Wang L, Ding HY, Weng CY, Yen JH (2004) Glossogyne tenuifolia acts to inhibit inflammatory mediator production in a macrophage cell line by down-regulating LPS-induced NF-KB. J Biomed SCi 11(2):186-199

Wu MJ, Huang CL, Lian TW, Kou MC, Wang L (2005a) Antioxidant activity of Glossogyne tenuifolia. J Agric Food Chem 53:6305-6312

Wu MJ, Weng CY, Ding HY, Wu PJ (2005b) Anti-inflammatory and antiviral effects of Glossogyne tenuifolia. Life Sci 76:1135-1146 
Yang JH, Tsai SY, Han CM, Shih CC, Mau JL (2006) Antioxidant properties of Glossogyne tenuifolia. Am J Chin Med 34:707-720

Xu HY (1972) Illustrations of Chinese herbs in Taiwan, Committee on Chinese Medicine and Pharmacy. Department of Health, Executive Yuan, Taiwan, p 308

Yamada Y, Shoyama Y, Nishioka I, Kohda H, Namera A, Okamoto T (1991)

Clonal micropropagation of Gentiana scabra Bunge var. buergeri Maxim. and examination of the homogeneity concerning the gentiopicroside content.

Chem Pharm Bull 39:204-206

doi:10.1186/s40529-014-0045-7

Cite this article as: Chen et al.: In vitro propagation and analysis of

secondary metabolites in Glossogyne tenuifolia (Hsiang-Ju) - a medicinal plant native to Taiwan. Botanical Studies 2014 55:45.

\section{Submit your manuscript to a SpringerOpen ${ }^{\circ}$} journal and benefit from:

- Convenient online submission

- Rigorous peer review

- Immediate publication on acceptance

- Open access: articles freely available online

- High visibility within the field

- Retaining the copyright to your article

Submit your next manuscript at $>$ springeropen.com 